\title{
Factors affecting green banking practices: Exploratory factor analysis on Vietnamese banks
}

\author{
TRAN THI THANH TU \\ University of Economics and Business, Vietnam National University - tuttt@vnu.edu.vn \\ NGUYEN THI PHUONG DUNG \\ University of Economics and Business, Vietnam National University
}

\begin{abstract}
ARTICLE INFO ABSTRACT
\end{abstract}
Article history:

Received:

Nov. 10, 2016

Received in revised form:

Feb. 10, 2017

Accepted:

Mar. 31, 2017

Keywords:

Green banking

Factors

Green finance

EFA analysis

Vietnamese banks
This paper aims at studying the factors affecting green banking practices in Vietnam and the role of green banking in sustainable development of the Vietnamese economy. A large scale survey conducted with 32 banks and financial organizations in Vietnam to obtain 329 questionnaire forms in the period from May to July 2016 provides evidence for the research. By using EFA analysis and the regression model, we find that understanding the definitions of green banking, the current activities of green banking, the advantages in developing green banking, and the focused sectors have positive relationships with the willingness of Vietnamese banks to adopt green banking practices, whereas the barriers have negative relationships with the willingness to utilize green banking services among Vietnamese banks. From the research findings, we suggest some solutions to not only enhance the understanding of the importance of green banking in economic development but also improve the willingness to follow green banking practices among Vietnam's banking institutions. 


\section{Introduction}

In the model of green growth that developing countries including Vietnam are pursuing, the role of green bank in providing banking and financial green services are increasingly important to the success of the green growth model and sustainable development of the whole Vietnamese economy. Numerous studies have shown the inevitable trend of the development of green banking model through providing banking and financial green services (Kaeufer, 2010, González et al., 2008) and the impact of providing green banking services to green banking operations, contributing to the environment as well as ensuring sustainable and green growth (Yang \& Ahmed, 2009, Imeson \& Sim, 2010). However, can green bank practices be applied in Vietnam? Which green banking practices would be appropriate in the context of Vietnam's banking system to meet current requirements of sustainable development? What are difficulties that Vietnamese banks will face? What are the advantages if these banks adopt green banking practices? What should Vietnamese Government and stakeholders undertake to support for green bank services? All of these will be addressed in this research.

Apart from the introduction, the remainder of this paper is divided into five sections, including the literature review on green banking definitions, green banking practices, and green banking challenges in Section 2, the research methodology presented in Section 3, the findings and discussions reported in Section 4, followed by Section 5, which proposes some solutions and policy implications for promoting green banking practices among Vietnamese banks.

\section{Literature review}

\subsection{Definitions of green banking}

In recent years the term "green banking" has emerged as a strategic development direction in the banking sector. There are numerous studies providing the definitions of green banking.

Generally, banks themselves are considered environment-friendly institutions with their operational activities because their internal environmental and social goals are fairly straightforward. However, sustainable development can be affected greatly by the activities of customers of the banks, such as those of steel, cement, chemicals fertilizer, power, textiles, etc. companies, which cause a great deal of carbon emission and environmental pollution. Therefore, as a major financial source of investment and economic development, the banking sector plays a crucial role in promoting sustainable development. 
According to the International Institute for Sustainable Development (IISD), integration of sustainable development into the banking sector has two key directions: (i) pursuit of environmental and social responsibility in a bank's operations through environmental initiatives (such as recycling programs or improvements in energy efficiency) and socially responsible initiatives (such as support for cultural events, improved human resource practices and charitable donations); and (ii) integration of sustainability into a bank's core businesses through the integration of environmental and social considerations into product design, mission policy, and strategies (e.g., integration of environmental criteria into lending and investment strategy and development of new products that provide environmental businesses with easier access to capital).

Rahman et al. (2013) verified that green banking refers to the banking business conducted in such areas and in such a way that enables the overall reduction of external carbon emission and internal carbon footprint. To aid the reduction of external carbon emission, banks should finance green technology and pollution-reducing projects. To reduce internal carbon footprint, banks are supposed to decrease their massive use of energy (e.g., lighting, air conditioning, electronic/electrical equipment, etc.).
Kaeufer (2010) suggested the 5-level development of green banking:

Level 1 (unfocused corporate activities): at this level banks involve themselves in green banking activities by sponsoring green events and public works which are not considered their main activities.

Level 2 (isolated business practices): banks separate green banking activities from their conventional banking activities. However, the percentage of green banking practices is rather small.

Level 3 (systematic business practices): at this level social and green principles and practices are the basis for the majority of banks' products. The main focus of the bank is the green impact of every business activity by emphasizing the four levels: people/places, processes, principles, and purpose.

Level 4 (strategic ecosystem innovation): by actively balancing strategic ecosystems, green banking activities are not limited to the scope of the banking sector, but they spread across the network, alliance, community dialogue, or the whole ecosystem to achieve sustainable development.

Level 5 (intentional ecosystem innovation): banks perform similar green banking activities as they do at level 4 , but at level 
5 , a socially responsible and green bank intends to address the ecosystem actively.

Bihari (2011) emphasized that green banking promotes social responsibility where banks consider before financing a project whether it is environment-friendly and has any future environmental implications. Green banking helps shift banks' objectives from "profit only" to "profit with responsibility."

Lalon (2015) argued that green banking is any form of banking from which a nation gets environmental benefits. A conventional bank becomes a green bank by directing its core operations toward the betterment of environment. It means developing inclusive banking strategies which will ensure substantial economic development and promote environmentfriendly practices.

As documented by Singh and Singh (2012), a green bank is like a normal bank, which considers all the social and environmental factors, aiming at protecting the environment and conserving natural resources. It is also called an ethical bank or a sustainable bank. Green banking means combining operational improvements and technology as well as changing client habits in banking business. From the aspect of banking professionals, green banking involves sustainability, ethical lending, conservation, and energy efficiency.
According to Meena (2013), green banking refers to the banking business that helps in reducing external carbon emission overall through financing green technology and pollution reducing projects. The banking sector can play an intermediary role between economic development and environmental protection because it provides major sources of financing for industrial projects, which cause maximum carbon emission. Green banking is a component of the global initiative by a group of stakeholders to save the environment. Green financing is regarded as a part of green banking, contributing greatly to the transition to resource-efficient and lowcarbon industries, for example, through financing green technology and pollution reducing projects.

In short, there exist various interpretations of the definition of green banking. However, in this paper green banking is considered any kind of initiative banking practices for sustainable development, taking into account the social and environmental impacts through their own environmental-friendly internal operations and green financing for their customers.

\subsection{Practices of green banking}

Green banking practices have developed in various forms. Green financial products and services include loans, de- 
posits, and settlement services in accordance with environmental requirements. Green banking includes green bank loans with financial concessions for environment-friendly products and projects such as green lending, fuel-efficient vehicles, green building projects, housing and house furnishing loans for installing the solar energy system, etc. (Singh, 2015). Green banking also requires environmental standards for lending (e.g., banks follow environmental standards for loans, which will make business owners change their operations to environment-friendly business (Meena, 2013). The typical green banking practices are as follows:

(i) Low-interest loans: Using subsidy from the government, the central bank, and green funds, commercial banks give low interest loans for green investments in the early periods of green banking development (Chaurasia, 2014).

(ii) Special loan: funded by international organizations to support the development of a certain industry/business such as renewable energies, energy efficiency, agricultural production, green building, and so forth, this kind of loan is deemed as the pilot model of green banking (e.g., series of Rural Finance 1, 2, 3 funded by the World Bank in Vietnam) (Tran \& Tran, 2015). (iii) Green credit standards: A special kind of credit provided to enterprises by commercial banks is based on certain requirements of environmental standards. These requirements could be associated with environment standards issued by the Ministry of Environment and the provincial environmental department (Zhang et al., 2011).

(iv) Investment funds: Used for financing SMEs' green investments in packages with consultant services in protecting environment and sustainable development, these funds are contributed by individuals or institutional investors. These successful experiences could be seen in the Root Capital model in Africa and Latin America. Root Capital supports small and growing businesses that adopt responsible environmental practices such as training farmers in sustainable production techniques, utilizing clean and appropriate technologies, etc. By providing capital and financial training to small and growing businesses that value environmental stewardship, Root Capital builds sustainable livelihoods in Africa and Latin America (Root Capital, 2016).

(v) Electronic banking: Banks should apply the electronic banking to promote environment- friendly practices and reduce the carbon footprint from banking operations now that it offers them cost sav- 
ing. E-banking services include online enquiry, e-payments, e-transfer, mobile banking, and so on (Tran \& Tran, 2015; Singh, 2015).

(vi) Green buildings: Banks provide loans for customers who use, or invest in, green buildings, which reduce the carbon footprint by, for instance, installing solar energy systems or utilizing energy-saving equipment. Bahl (2012) described carbon footprint reduction by green buildings as the top priority in green banking strategies.

(vii) SMART: Specific, measurable, attainable, realistic, and timely green objectives considered as the internal targets are to reduce the carbon footprint in combination with timelines in banks' operations (Nath et al., 2015).

\subsection{Challenges of green banking}

Apart from the benefits offered to banks, green banking faces numerous confronting challenges, which can be analyzed as follows:

(i) Lower cash flow in short terms of green investments/projects: The green investments/projects normally features long-term payback periods with lower cash flow in the short run. Before making a loan, banks should evaluate these risks via a cash flow analysis or cost and benefit analysis for these green investments/projects. This will take time and will be costly for banks; hence, it may be difficult to finance many projects at the same time.

(ii) Lack of reliable data on the environmental impact assessment of green investments/projects: Banks need reliable data to assess the environmental impacts of green investments/projects. The reliable data are normally not available for banks. In addition, banks cannot assess the reliability of the data by themselves, yet need to collect reliable data on assessing the pollution impacts instead. They may also need professional assessments by independent environmental auditors (Zhang et al., 2011).

(iii) Long start-up time, low numbers of customers: Green banking activities normally takes longer time for preparation and implementation than the typical ones. Banks appraise the projects of customers based on specific environmental standards. These standards may restrict the numbers of customers (Biswas, 2011).

(v) Low profit in short terms: The main objective of green banking is to support "green" projects/investments with a focus on promoting sustainable development and protecting the environment. These projects/investments may not concentrate on making profit. This will lead to lower profit for the banks.

(vi) Higher operating costs: Green banks need to invest a great deal of capital 
in educating and regularly training specialized, talent, and skillful bank staff for assessment of environmental impacts of investments/projects. Bank staff also needs to have additional background and experiences in dealing with green investments/projects. Also, banks occasionally need to invest in modern technologies in assessing environmental impacts of "green" projects/investments (Rahman \& Barua, 2016).

(vii) Reputation risks: Focusing on green banking help banks enhance their reputation in long terms. However, due to the difficulty of assessing the environmental impacts of projects/investments, banks also have to face risks of financing "dirty" projects which cannot be regarded as being "green" or may damage the environment and sustainable development. The overall reputation of banks will be affected by funding these kinds of projects (Biswas, 2011).

(viii) Lack of formal guidlines on green banking: Green banking is a new concept in the banking industry, especially in developing countries like Vietnam. Therefore, a formal legislation framework for green banking has not been promulgated by the Government. In addition, the legislation frame for assessing "green" projects are not formally set up and consolidated between governmental agencies (Biswas, 2011; Rajput et al., 2013).

\subsection{Previous research on green bank- ing in Vietnam}

At present, there are extremely few studies on green banking in Vietnam. Hong (2013) pointed out two fundamental challenges to implementing green finance and banking in Vietnam: (i) social awareness of financial and banking activities is limited, and green growth is considered the cost to the environment rather than business opportunities; and (ii) lack of regulations and laws on green banking and finance and lack of mechanisms to support the development of financial institutions and green banks.

An independent study of PanNature which examined 19 major commercial banks in Vietnam (based on capital and assets) showed that only Sacombank by itself builds risk management system credit for the environment and society. Accordingly, the project introduced to Sacombank is classified based on the level of impact on the environment, which allows the bank to provide credit decisions for the project and set the monitoring plan and satisfactory test agreements with customers to minimize the impact of the project on the environment (PanNature, 2012).

Tran and Tran (2015) analyzed the situations of green banking practices in 
Vietnam. It was argued that there are few in-depth studies conducted in Vietnam on the green bank, and no research has proposed the suitable green banking model for Vietnamese banks. According a survey undertaken in June 2012 by the State Bank of Vietnam (SBV) of 54 commercial banks, it was found that for $91 \%$ of them, there exists no clear policy at the banking level on the green growth, whereas 35\% do not gain knowledge about the definitions of environment and social issues. In particular, 89\% admitted that the SBV's regulations still lack the management of social environment in financial industry. Generally, among Vietnamese banks there is a lack of experience of new technologies, which causes them to get into trouble with new energy credit such as the bias about risk appraise on green projects. In Vietnam there is currently no bank which is genuinely considered as green bank; however, there exist several green products for green investments in Vietnamese commercial banks.

\section{Research Methodology}

This research uses a questionnaire survey after conducting preliminary interviews and a pilot survey with several banks in Hanoi, and one of the two biggest centers of Vietnam. After the pilot survey, we modified the questionnaire based on the feedback of this pilot survey. The questionnaire consists of two parts, namely general information (Part I) and the situations of green banking in the banks (Part II). Part I includes questions about general characteristics of the banks such as the main field, the year of establishment, the detailed information of the respondents, and years of experience in the banking sector. Part II consists of questions concerning the acknowledgement of the respondents on green banking, the current practices of green banking in the banks, the environmental standard applied in appraising credits, the assessment on the roles of green banking in the banks as well as in the whole Vietnamese economy, and the strategies to develop green banking among banking institutions in the future. Various kinds of questions, namely closed-ended and open-ended questions, and a 5-point Likert scale have been used to ensure the accuracy of responses.

The pilot survey was implemented in May 2016 with several banks in Hanoi, all of which were selected from the following sources: the Vietnamese General Statistics Office, the Banking Strategy Institute of Vietnam, the Vietnam Banks Association (the list of banks in Vietnam is provided by the State Bank of Vietnam). We identified a few criteria for selecting the banks 
in our survey as follows. First, the banks which have large revenues were the first priority of the selection due to the fact that green loans require high initial investment costs (Singh, 2015). Second, both sateowned banks and non-state owned banks were selected because prior research has shown that green banking develops strongly in spite of the ownership forms. Third, the respondents had to be either heads/vice heads of departments of head offices or directors/vice directors of bank branches to ensure the reliability and relevance of the answers.

We delivered official questionnaire forms to 32 selected banks in Vietnam from June 2016 to August 2016. Reminders via phone or email were sent one month after the first mailing to those without responses. By the end of August 2016 we received 329 responses from 32 commercial banks in Vietnam. The SPSS 22.0 was used to analyze the data. All respondents had spent at least 3 years working in the banking sector. Among them $83 \%$ have 5 to 7 years of experience. The respondents are either heads/vice heads working in head offices or directors/vice directors of bank branches. These characteristics of the respondents are significant to evaluate the reliability of the survey results.
The objective of this study is to evaluate the exploratory factors which influence the willingness of Vietnamese banks to adopt green banking practices. Based on the survey and literature review, we take into account five exploratory factors which may affect the willingness of Vietnamese banks to adopt green banking practices. They include: (i) understanding the definitions of green banking; (ii) current activities of green banking; (iii) barriers to the adoption of green banking practices; (iv) advantages in developing green banking; and (v) focused business sectors of green banking. The factors are symbolized as Definition, Activity, Barrier, Advantage, and Concentrate (as shown in Table 1). First, we implement the reliability analysis to determine the reliability of all the factors using Cronbach's alpha. Second, we conduct the exploratory factor analysis (EFA), which tests the trend of gathering among variances to re-confirm the accuracy of the theoretical framework. Third, we use the regression analysis to test the interactions among the five factors and the dependent variable.

Previous international studies showed that there are various definitions and forms of green banking (Kaeufer, 2010; Rahman et al., 2013; Sigh \& Sigh, 2012; Lalon, 2015). Kaeufer (2010) demonstrated five levels of the development of green banking, and argued that the definitions of 
green banking vary in an equivalent way with the five development levels. Understanding the definitions of green banking is the basis for the banks to adopt green banking practices. If Vietnamese commercial banks penetrate the definitions of green banking, it would be more certain that they can follow green banking practices. Therefore, we suppose that understanding the definitions of green banking would have a positive impact on the willingness of Vietnamese banks to adopt green banking practices.

H1. Understanding the definitions of green banking has a positive influence on the willingness of Vietnamese banks to adopt green banking practices.

As PanNature (2012) and Tran and Tran (2015) found that there exist several green products in commercial banks in Vietnam, we suppose that Vietnamese banks would implement more green banking practices based on their current green products. Also, the current activities of green banking show that banks would consider developing the green development strategies. Thus, it can be hypothesized that the more the current activities of green banking, the more willingly banks adopt green banking practices in the future.

H2. The current activities of green banking have a positive influence on the willingness of Vietnamese banks to adopt green banking practices.

Still. many previous investigations indicated that green banking has faced numerous confronting challenges during its development. Some typical challenges include lower cash flows in short terms of green investments/projects, lack of reliable data on the environmental impact assessment of green investments/projects (Zhang et al., 2011), long start-up time, low numbers of customers and reputation risks (Biswas, 2011), low profit in short terms, higher operating costs (Rahman \& Barua, 2016), and lack of formal guidelines on green banking (Biswas, 2011; Rajput et al., 2013). Also, in Vietnam Tran and Tran (2015) found that Vietnamese banks have to cope with quite a few obstacles which restrict their green banking products. We, therefore, argue that the current barriers to green banking impact negatively on the willingness of Vietnamese banks to adopt green banking practices.

H3. The current barriers to green banking are negatively associated with the willingness of Vietnamese banks to adopt green banking practices.

Green banking is supposed to be the future of the banking sector. Green banking brings various advantages such as protecting the environment through automation and online banking (Tran \& Tran, 2015) or 
financing investments/projects which involve sustainable development and green growth (Lalon, 2015). It is undeniable that green banking is beneficial to not only the banking industry but also the whole economy and environment in the long run (Yadav \& Pathak, 2013). Hence, it is confirmed that the advantages of green banking will have positive impacts on banks' willingness to adopt green banking practices.

H4. The advantages of green banking have a positive relationship with the willingness of Vietnamese banks to adopt green banking practices.

Different sectors have different levels of demand for green banking services. It depends on the development periods of green banking. Bahl (2012) referred carbon footprint reduction by green buildings to the top priority in green banking strategies. Nath et al. (2014) documented that at first Indian banks promote the development of green power by installing wind- mills for captive use and the carbon disclosure projects for sectors in the economy. Vivid Economics and McKinsey (2011) demonstrated that Green Investment Bank (GIB) could help expand potential investment in environmentally beneficial projects, for example, on sea wind energy, renewable electricity or energy, and carbon emissions. Green banking includes green bank loans with financial concessions for environment-friendly products and/or projects such as green lending, fuel efficient vehicles, green buildings, housing and house furnishing loans for installing solar energy system, etc. (Singh, 2015). Therefore, we suggest that Vietnamese banks should focus on several selected sectors which are supposed to have higher needs for green banking services, and this concentrated effort would allow for banks' promotion of green banking practices.

H5. Focused sectors have positive effects on the willingness of Vietnamese banks to adopt green banking practices.

\section{Table 1}

Variable description

\begin{tabular}{lll}
\hline $\begin{array}{l}\text { Independent vari- } \\
\text { ables }\end{array}$ & Notation & \multicolumn{1}{c}{ Interpretation } \\
\hline $\begin{array}{l}\text { Definitions } \\
\text { green banking }\end{array}$ of & DEF 1 & $\begin{array}{l}\text { Providing loans for projects which do not cause damages to the en- } \\
\text { vironment and/or reduce Carbon Dioxide Emissions (CO2) }\end{array}$ \\
DEF 2 & $\begin{array}{l}\text { Providing loans for energy efficiency and renewable energy pro- } \\
\text { jects }\end{array}$
\end{tabular}




\begin{tabular}{|c|c|c|}
\hline $\begin{array}{l}\text { Independent vari- } \\
\text { ables }\end{array}$ & Notation & Interpretation \\
\hline & DEF 3 & $\begin{array}{l}\text { Promoting environment-friendly practices and reducing carbon } \\
\text { footprint from banking activities through using online banking in- } \\
\text { stead of branch banking; paying bills online instead of mailing them } \\
\text { inside the banks themselves, etc. }\end{array}$ \\
\hline & DEF 4 & $\begin{array}{l}\text { Providing loans for projects under which assessment of environ- } \\
\text { mental impacts and sustainable development is requested }\end{array}$ \\
\hline & DEF 5 & $\begin{array}{l}\text { Refusing to grant credit to projects which exert negative impacts on } \\
\text { the environment }\end{array}$ \\
\hline & DEF 6 & $\begin{array}{l}\text { Developing specific green products and services and adding them } \\
\text { to the list of traditional banking products }\end{array}$ \\
\hline & DEF 7 & $\begin{array}{l}\text { Actively proposing initiatives to balance the ecosystems and pro- } \\
\text { mote sustainable growth }\end{array}$ \\
\hline & DEF 8 & $\begin{array}{l}\text { Giving favorable conditions (lower interest rates, softer collateral } \\
\text { conditions, etc.) to green investments/ projects }\end{array}$ \\
\hline \multirow{7}{*}{$\begin{array}{l}\text { Current activities } \\
\text { in green banking }\end{array}$} & ACT 1 & Internet banking \\
\hline & ACT 2 & $\begin{array}{l}\text { Providing loans for projects involved in energy efficiency and/or } \\
\text { green/clean technologies }\end{array}$ \\
\hline & ACT 3 & Providing loans for projects involved in renewable energy \\
\hline & ACT 4 & $\begin{array}{l}\text { Conducting activities inside the banks to protect the environment } \\
\text { (reducing carbon footprint from banking activities, online banking, } \\
\text { paying bills online instead of mailing them, etc.) }\end{array}$ \\
\hline & ACT 5 & $\begin{array}{l}\text { Requiring enterprises which apply for loans to obey environmental } \\
\text { standards }\end{array}$ \\
\hline & ACT 6 & Supporting other industries/sectors to promote green growth \\
\hline & ACT 7 & $\begin{array}{l}\text { Giving favorable conditions (lower interest rates, softer collateral } \\
\text { conditions, etc.) to green investments/ green projects }\end{array}$ \\
\hline
\end{tabular}

BAR 1 Reducing bank competitiveness in short terms

BAR 2 High investment costs and less profits in green banking activities 


\begin{tabular}{|c|c|c|}
\hline $\begin{array}{l}\text { Independent vari- } \\
\qquad \text { ables }\end{array}$ & Notation & Interpretation \\
\hline \multirow{12}{*}{$\begin{array}{l}\text { Current barriers to } \\
\text { the adoption of } \\
\text { green banking }\end{array}$} & BAR 3 & $\begin{array}{l}\text { High costs, long pay-back periods, and high risks recorded with en- } \\
\text { vironment-friendly projects }\end{array}$ \\
\hline & BAR 4 & Difficulties and complexity in assessing green projects \\
\hline & BAR 5 & $\begin{array}{l}\text { Lack of capable and well-trained staff in appraising green cred- } \\
\text { its/loans }\end{array}$ \\
\hline & BAR 6 & $\begin{array}{l}\text { No specific guidance issued by the State Bank of Vietnam for ap- } \\
\text { praising green credits/loans }\end{array}$ \\
\hline & BAR 7 & $\begin{array}{l}\text { Few internal regulations for appraising and assessing green cred- } \\
\text { its/loans }\end{array}$ \\
\hline & BAR 8 & $\begin{array}{l}\text { Lack of legal framework for supporting green banking proposed by } \\
\text { the Government }\end{array}$ \\
\hline & BAR 9 & Vietnam's commitments to international and regional agreements \\
\hline & BAR 10 & Low demand for green credits/loans \\
\hline & BAR 11 & $\begin{array}{l}\text { Customers' insufficient awareness of the importance of green bank- } \\
\text { ing services }\end{array}$ \\
\hline & ADV 1 & In the long run, increasing bank competitiveness and reputation \\
\hline & ADV 2 & $\begin{array}{l}\text { Being in accordance with sustainable economic development and } \\
\text { green growth strategies of Vietnam }\end{array}$ \\
\hline & ADV 3 & $\begin{array}{l}\text { Fulfilling commitments during Vietnam's accession to interna- } \\
\text { tional organizations }\end{array}$ \\
\hline
\end{tabular}

Advantages of ADV 4 Higher profits for banks in long terms

green banking

ADV 5 Meeting customers' demand for green credits/loans

ADV 6 Favorable supports given to the banks which provide green credits/loans by the State Bank of Vietnam

Favorable supports given to the banks which provide green cred-

ADV 7 its/loans by international organizations and international financial institutions

CON 1 Agriculture, forestry, and fishery 


\begin{tabular}{|c|c|c|}
\hline $\begin{array}{l}\text { Independent vari- } \\
\text { ables }\end{array}$ & Notation & Interpretation \\
\hline \multirow{10}{*}{$\begin{array}{l}\text { Focused sectors of } \\
\text { green banking }\end{array}$} & CON 2 & Hydroelectricity \\
\hline & CON 3 & Wind electricity \\
\hline & CON 4 & Waste management \\
\hline & CON 5 & Green tourism \\
\hline & CON 6 & Oil refinery \\
\hline & CON 7 & Geothermal energy \\
\hline & CON 8 & Biological energy \\
\hline & CON 9 & Solar energy \\
\hline & CON10 & Energy-efficient products \\
\hline & CON11 & Recycled products and energy-efficient investments \\
\hline
\end{tabular}

\section{Results and discussions}

\subsection{Reliability analysis of the data}

In statistics the Cronbach's alpha is used to estimate the reliability of the data (Anderson et al., 2010). Therefore, we initially analyze the reliability of the data using Cronbach's alpha test to examine the internal consistency of the five factors. Specifically, the scales which have Cronbach's alpha coefficients greater than or equal to 0.6 will be accepted in our study (Ritter, 2010). The item-total corre- lation indicates the correlation of one variable with others in the same scale. The value which is greater than 0.3 of the itemtotal correlation will be accepted, and the smaller will be rejected. The results of Cronbach's alpha test with the data of the Vietnamese banks are presented in Table 2. Sig $=0.000$ implies that the data is considered reliable. All the five factors have Cronbach's alpha coefficients higher than 0.6 ; therefore, they reflect high reliability and can be used for further analysis. 


\section{Table 2}

Results of Cronbach's alpha test

\begin{tabular}{|c|c|c|c|c|}
\hline \multicolumn{5}{|c|}{ Item-total statistics } \\
\hline & Scale mean if item deleted & $\begin{array}{l}\text { Scale variance if } \\
\text { item deleted }\end{array}$ & $\begin{array}{l}\text { Corrected item-total } \\
\text { correlation }\end{array}$ & $\begin{array}{l}\text { Cronbach's alpha if } \\
\text { item deleted }\end{array}$ \\
\hline DEF1 & 24.56 & 25.501 & .664 & .874 \\
\hline DEF2 & 24.58 & 25.298 & .710 & .870 \\
\hline DEF3 & 25.07 & 25.234 & .624 & .879 \\
\hline DEF4 & 24.69 & 25.217 & .699 & .871 \\
\hline DEF5 & 24.70 & 24.987 & .558 & .888 \\
\hline DEF6 & 24.96 & 25.508 & .684 & .873 \\
\hline DEF7 & 25.13 & 25.747 & .708 & .871 \\
\hline DEF8 & 25.00 & 24.830 & .690 & .872 \\
\hline ACT1 & 20.85 & 15.22 & .716 & .674 \\
\hline ACT2 & 20.92 & 15.10 & .717 & .673 \\
\hline ACT3 & 20.86 & 16.03 & .517 & .710 \\
\hline ACT4 & 20.91 & 14.86 & .672 & .676 \\
\hline ACT5 & 20.96 & 15.98 & .640 & .693 \\
\hline ACT6 & 21.13 & 15.42 & .610 & .691 \\
\hline ACT7 & 20.46 & 17.56 & .011 & .891 \\
\hline BAR1 & 31.48 & 33.191 & .474 & .848 \\
\hline BAR2 & 31.53 & 34.280 & .270 & .865 \\
\hline BAR3 & 31.32 & 34.299 & .279 & .864 \\
\hline BAR4 & 31.12 & 31.901 & .624 & .838 \\
\hline BAR5 & 31.05 & 31.026 & .667 & .834 \\
\hline BAR6 & 31.12 & 31.789 & .576 & .841 \\
\hline BAR7 & 31.21 & 31.210 & .632 & .836 \\
\hline
\end{tabular}




\begin{tabular}{|c|c|c|c|c|}
\hline \multicolumn{5}{|c|}{ Item-total statistics } \\
\hline & Scale mean if item deleted & $\begin{array}{l}\text { Scale variance if } \\
\text { item deleted }\end{array}$ & $\begin{array}{l}\text { Corrected item-total } \\
\text { correlation }\end{array}$ & $\begin{array}{c}\text { Cronbach's alpha if } \\
\text { item deleted }\end{array}$ \\
\hline BAR8 & 31.25 & 30.764 & .635 & .836 \\
\hline BAR9 & 31.57 & 30.687 & .600 & .839 \\
\hline BAR10 & 31.37 & 31.777 & .637 & .837 \\
\hline BAR11 & 31.24 & 31.410 & .669 & .834 \\
\hline ADV1 & 19.44 & 13.517 & .692 & .875 \\
\hline ADV2 & 19.16 & 13.795 & .676 & .877 \\
\hline ADV3 & 19.09 & 13.611 & .696 & .875 \\
\hline ADV4 & 19.67 & 13.034 & .704 & .875 \\
\hline ADV5 & 19.44 & 14.021 & .682 & .877 \\
\hline ADV6 & 19.38 & 13.697 & .682 & .877 \\
\hline ADV7 & 19.25 & 13.663 & .693 & .875 \\
\hline CON1 & 34.22 & 34.817 & .657 & .846 \\
\hline CON2 & 34.88 & 37.239 & .273 & .877 \\
\hline CON3 & 34.26 & 34.635 & .647 & .846 \\
\hline CON4 & 34.05 & 34.208 & .753 & .839 \\
\hline CON5 & 34.57 & 35.768 & .517 & .855 \\
\hline CON6 & 34.85 & 37.277 & .283 & .876 \\
\hline CON7 & 34.65 & 35.112 & .577 & .851 \\
\hline CON8 & 34.23 & 34.619 & .646 & .846 \\
\hline CON9 & 34.09 & 34.468 & .689 & .843 \\
\hline CON10 & 34.25 & 34.932 & .658 & .846 \\
\hline CON11 & 34.29 & 34.990 & .654 & .846 \\
\hline
\end{tabular}




\subsection{Exploratory factor analysis}

Second, exploratory factor analysis (EFA) is done to test the trend of gathering among variances to re-confirm the accuracy of the theoretical framework. EFA is a statistical technique that is employed to reduce data to a smaller set of variables and to explore the underlining structure of the data. It is also used to identify the structure of the relationships between the variables based on KMO measure. If KMO has values ranging between 0.5 and
1.0 and sig. is smaller than 0.5 , the factor analysis is appropriate (DeCoster, 1998). After the first EFA, we exclude two variables, namely BAR 1 and CON 5, because their KMO values are smaller than 0.5. After the second EFA, we reject DEF5 for the same reason. Then, in the third EFA test, we receive the results as shown in Table 3. In total the KMO value measures $91.6 \%$ of the sampling adequacy with the sig. value of 0.000 . All these variables reported in Table 3 are accepted because their factor loadings values are higher than 0.5 .

\section{Table 3}

EFA results

KMO and Bartlett's test

\begin{tabular}{llc}
\hline Kaiser-Meyer-Olkin measure of sampling adequacy & .916 \\
\hline Bartlett's test of sphericity & Approx. chi-square & 8961.048 \\
\cline { 2 - 3 } & df & 630 \\
\cline { 2 - 3 } & sig. & .000
\end{tabular}

\begin{tabular}{lccccc}
\hline & \multicolumn{5}{c}{ Rotated component matrix $^{\mathrm{a}}$} \\
\hline & 1 & 2 & Component & 5 \\
\hline CON9 & .813 & & 4 & \\
CON4 & .779 & & & \\
CON8 & .722 & & & \\
CON3 & .702 & & & \\
CON10 & .696 & & & \\
\end{tabular}




\begin{tabular}{|c|c|c|c|c|c|}
\hline \multicolumn{6}{|c|}{ Rotated component matrix ${ }^{a}$} \\
\hline & \multicolumn{5}{|c|}{ Component } \\
\hline & 1 & 2 & 3 & 4 & 5 \\
\hline CON1 & .681 & & & & \\
\hline CON11 & .671 & & & & \\
\hline CON7 & .562 & & & & \\
\hline BAR7 & & .749 & & & \\
\hline BAR5 & & .737 & & & \\
\hline BAR8 & & .727 & & & \\
\hline BAR11 & & .719 & & & \\
\hline BAR10 & & .685 & & & \\
\hline BAR4 & & .685 & & & \\
\hline BAR6 & & .666 & & & \\
\hline BAR9 & & .648 & & & \\
\hline DEF7 & & & .763 & & \\
\hline DEF4 & & & .705 & & \\
\hline DEF6 & & & .702 & & \\
\hline DEF2 & & & .695 & & \\
\hline DEF3 & & & .669 & & \\
\hline DEF8 & & & .633 & & \\
\hline DEF1 & & & .631 & & \\
\hline $\mathrm{ACT} 1$ & & & & .810 & \\
\hline $\mathrm{ACT} 2$ & & & & .791 & \\
\hline ACT4 & & & & .773 & \\
\hline ACT5 & & & & .746 & \\
\hline ACT6 & & & & .657 & \\
\hline ACT3 & & & & .613 & \\
\hline
\end{tabular}




\begin{tabular}{|c|c|c|c|c|c|}
\hline \multicolumn{6}{|c|}{ Rotated component matrix ${ }^{a}$} \\
\hline & \multicolumn{5}{|c|}{ Component } \\
\hline & 1 & 2 & 3 & 4 & 5 \\
\hline ADV4 & & & & & .736 \\
\hline ADV6 & & & & & .717 \\
\hline ADV5 & & & & & .706 \\
\hline ADV1 & & & & & .683 \\
\hline ADV7 & & & & & .669 \\
\hline ADV3 & & & & & .551 \\
\hline ADV2 & & & & & .532 \\
\hline
\end{tabular}

\subsection{Regression analysis}

We perform a regression analysis for evaluating whether or not the willingness of the Vietnamese banks to adopt green banking practices is affected by the five factors including Definition, Activity, Barrier, Advantage, and Concentrate. The positive relationship means that the higher/lower values of the determinants are associated with the higher/lower levels of the intention to follow green banking practices. The results of the regression analysis to test the interaction among these five variables and the dependent variable are shown in Table 4 . The adjusted Rsquared value in the regression model is $83.3 \%$, which emphasizes that the willingness can be explained by the five varia- bles, including: (i) understanding the definitions of green banking; (ii) the current activities of green banking; (iii) the barriers to the adoption of green banking practices; (iv) the advantages of developing green banking; and (v) the focused business sectors of green banking. Therefore, we accept the following regression model:

$S E R=-18.714+1.780 * C O N-0.705$ * BAR + $1.266 * D E F+1.046 * A C T+$ $2.420 * A D V$

In addition, the five hypothesis, namely $\mathrm{H} 1, \mathrm{H} 2, \mathrm{H} 3, \mathrm{H} 4$, and $\mathrm{H} 5$, are accepted. We can conclude that the understanding of the definitions of green banking, the current activities of green banking, the advantages in developing green banking, and the focused sectors have positive relationships with the willingness of Vietnamese banks 
to adopt green banking practices, which, in turn, are negatively associated with the current barriers to green banking.

\section{Table 4}

Regression results

Classification table ${ }^{\mathrm{a}}$

Predicted

\begin{tabular}{cccccc} 
& & & \multicolumn{2}{c}{ Dependent variable } & \\
\cline { 3 - 4 } & & 0 & 1 & Percentage correct \\
\hline Step 1 & $\begin{array}{c}\text { Dependent varia- } \\
\text { ble }\end{array}$ & 0 & 123 & 34 & 78.3 \\
\cline { 3 - 5 } & 1 & 31 & 202 & 86.7 \\
\cline { 3 - 5 } & Overall percentage & & & 83.3 \\
\hline
\end{tabular}

Variables in the equation

\begin{tabular}{|c|c|c|c|c|c|c|c|}
\hline & & B & S.E. & Wald & $\mathrm{df}$ & sig. & $\operatorname{Exp}(B)$ \\
\hline \multirow[t]{6}{*}{ Step $1^{\mathrm{a}}$} & CON_X1 & 1.780 & .322 & 30.556 & 1 & .000 & 5.929 \\
\hline & BAR_X2 & -.705 & .336 & 4.402 & 1 & .036 & .494 \\
\hline & DEF_X3 & 1.266 & .300 & 17.779 & 1 & .000 & 3.546 \\
\hline & ACT_X4 & 1.046 & .310 & 11.406 & 1 & .001 & 2.845 \\
\hline & ADV_X5 & 2.420 & .495 & 23.941 & 1 & .000 & 11.249 \\
\hline & Constant & -18.714 & 2.111 & 78.587 & 1 & .000 & .000 \\
\hline
\end{tabular}

a. Variable(s) entered on Step 1: CON_X1, BAR_X2, DEF_X3, ACT_X4, ADV_X5

4.4. The future of green banking in $\mathrm{Vi}$ etnam

We have asked the selected Vietnamese banks to assess the future of green banking in the banking sector of Vietnam.
As shown in Figure 1, a high percentage of respondents (75\%) agree that green banking is considered an important component in the medium- and long-run development strategy of their banks. Only $11 \%$ of these 
respondents believe that green banking is not planned in the medium- and long-run development strategy of their banks. Overall, this result shows that green banking is regarded as being critical in the Vietnam's banking sector in the future.

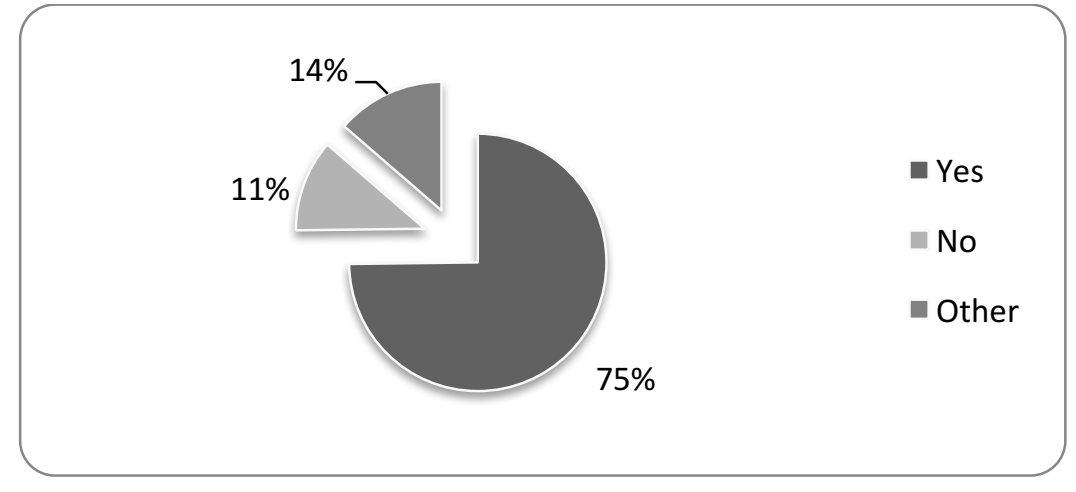

Figure 1. Future of green banking in medium- and long-run development strategy of the banks

Also, we have asked the respondents if are hydroelectricity and oil refinery. This green banking should focus on which busi- indicates that the Vietnamese banks have ness sectors in Vietnam. The answers are the general understanding of the sectors shown in Figure 2. The waste management harmful to the nature and environment. sector receives the highest level of agree- Hydroelectricity has recently been considment (mean $=3.782$ ); second ranked is so- ered a nonpolluting source but does have lar energy (mean $=3.76$ ), which is fol- large environmental impacts by changing lowed by biological energy; agriculture, the environment and affecting land use, forestry, and fishery; energy-efficient homes, and natural habitats in the nearby products, etc. The lowest ranked sectors area. 
Therecycled products, energy-efficient investment Energy-efficient products

Solar energy Biological energy Geothermal energy Oil refinery Green tourism Waste management Wind electricity Hydroelectricity Agriculture, forestry, and fishery

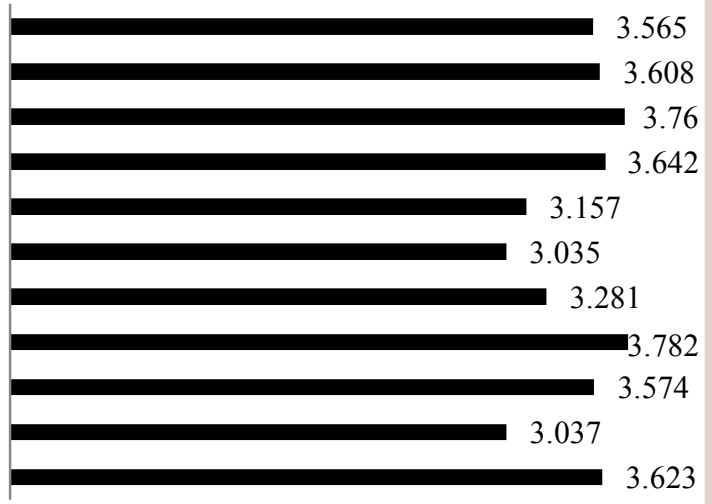

Figure 2. Focused sectors of green banking

Moreover, another purpose of our survey is to identify the kinds of support which the Vietnamese banks need to develop green banking in the future (as shown in Figure 3). According to the respondents, the most significant mode is from the Government and State Bank of Vietnam for credit policies and preferred interest rates. The second and third most significant kinds of support are respectively that given by the international organizations on green banking in Vietnam and that on the green growth policy received from the Vietnamese Government.
Therefore, it can be concluded that the Vietnamese banks do need macro-leveled support from the Government and SBV in developing green banking in the future. In addition, among these kinds the pioneer investments made by enterprises on green projects are considered the lowest ranked item to promote development of green banking among the banks. In other words, enterprises' needs for green banking do not have much effect on the green banking activities of Vietnamese banks in the future. 


\begin{abstract}
Formulation of a green banking model which can.. Specific support for green growth strategies given.. Pioneer investments made by enterprises in green..

Appreciation gained by society and potential. Sucessful experiences of the banks which have. Specific support from international organizations. Specific support from the Government and SBV.
\end{abstract}

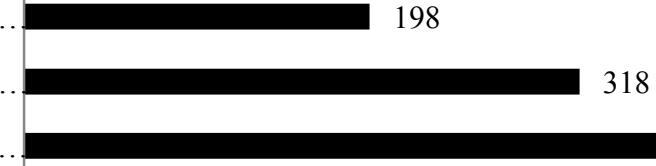

Figure 3. Different modes of support needed to develop green banking among Vietnamese banks

\section{Conclusion and implications}

It could be concluded txhat deployment of green banking is an inevitable trend in the development strategy of Vietnam's commercial banks. The fact that the awareness level, as well as the actual extent of implementation, of this model in the Vietnam's commercial banking system remains comparatively low. Handling the situation requires not only the genuine efforts of the commercial banks themselves, but also the support from the Government and the contributions particularly made by businesses and consumers:

5.1. For the commercial banks of Vietnam

Raising commercial bank management's understanding of green banking model: In order to successfully implement green banking, the first condition is to raise managers' awareness, especially that of senior leaders, of the commercial banks operating in Vietnam. From our EFA results, the factor that has the highest correlation with the willingness of banks to provide green banking services is the understanding of green banking shown by bank managers/leaders. Only when the managers of commercial banks in Vietnam perceive the definitions and different levels of green banking model can they provide support necessary for designing action plans and suitable business plans at each level of specific green bank development. Regarding the highest level of green banking, banks should promote green banking as a green development strategy for all their business plans as well as banking services. Particularly, it is bank leaders who should recognize the important role of green banking. 
Improving bank staff's capacity: To provide green products and services requires raising the capacity of bank staff, especially their ability to examine and evaluate environmental projects using novel technologies and techniques and to analyze the socioeconomic and environmental impacts of the projects in action. To do this commercial banks should seek for support from international organizations through technical assistance packages.

\subsection{For Vietnamese Government}

Developing and promulgating policies and measures that encourage adoption of green banking practices: The international experiences in developing green banking and the results of the survey show that the Government plays an crucial role in supporting the implementation of green banking. Specifically, the Government should have policies on taxes, fees, and credit in support of banks providing green services and products, especially in the first period of green banking application in Vietnam.

Applying a pilot green banking model: Currently, the Vietnam Development Bank (VDB) provides credit for development projects under support from the Government. VDB should be given the responsibility to provide green credit as a pilot project on green bank model. This bank should gain advantage as a development bank in the first period of green banking to provide credit for green investments.

Promulgating policies to encourage enterprises to implement green investments: A challenge to green banking activities is that enterprises and customers show no interest in them, so get no access to green credit that banks provide. Therefore, the Government should develop policies such as tax- or fee-preferential policies as well as financial loans suitable for the business sector to encourage enterprises to invest in technological innovation toward green technologies and green jobs, which creates competitive advantages in the enterprise market. This is imperative because the costs of constructing systems to minimize environmental pollution or facilitate clean production are often quite large, causing significant difficulties to businesses that desire to deploy these systems, especially small- and medium-sized ones which make up the majority of the Vietnam's economy.

Raising consumers' awareness of using green products: To encourage enterprises to invest in green investments/projects, it is also necessary to help consumers gain perception of using ecologically clean goods and products. Therefore, the Government should take measures to help foster customers' awareness through changing consumption habits, favoring "green" goods and products 


\section{Acknowledgment}

We would like to thank the National Fund for Science and Technology Development of Vietnam (NAFOSTED) for funding for the research entitled "The role of green banking in the transition of economic growth model and economy restructuring: International experiences and implications for Vietnam," from which this paper is extracted.

\section{References}

Anderson, R. D., Sweeney, J. D., Williams, A. T. (2010). Statistics for business and economics (11 Ed.). South-Western College Pub.

Bahl, S. (2012). The role of green banking in sustainable growth. International Journal of Marketing. Financial Services and Management Research, 1(2), 27-35.

Bihari, S. C. (2011). Green banking: Towards socially responsible banking in India. International Journal of Business Insights and Transformation, 4(1), 82-87.

Biswas, N. (2011). Sustainable green banking approach: The need of the hour. Business Spectrum, 1(1), 32-38.

Chaurasia, A. K. (2014). Green banking practices in Indian banks. The Journal of Management and Social Science, 1(1), 41-54.

DeCoster, J. (1998). Overview of factor analysis. Retrieved Mar 152016 from http://www.stathelp.com/factor.pdf

Gardiner, L., Grigoryeva, E., Mason, C. H. J., \& Morrison, N. (2007). Banking on sustainability: Financing environmental and social opportunities in emerging markets. Working Paper No. 39223. IFC E\&S, World Bank Group, Washington, DC.

Hong, V. X. N. (2013). Green finance and banking: Aid to green growth. Workshop of Green Finance and Banking. Germany International Organization-State Bank-Viet Nam Ministry of Finance, Hanoi.

International Institute for Sustainable Development. (n/d). Sustainable banking. Retrieved March 16, 2016 from https://www.iisd.org/business/banking/sus_banking.aspx

Kaeufer, K. (2010). Banking as a vehicle for socio-economic development and change: Case studies of socially responsible and green banks. Presencing Institute, Cambridge, MA.

Lalon, R. M. (2015). Green banking: Going green. International Journal of Economics, Finance and Management Sciences, 3(1), 34-42. doi: 10.11648/j.ijefm.20150301.15

Meena, R. (2013). Green banking: As initiative for sustainable development. Global Journal of Management and Business Studies, 3(10), 1181-1186.

Nath, V., Nayak, N., \& Goel, A. (2014). Green banking practices: A Review. International Journal of Research in Business Management, 2(4), 45-46. 
PanNature. (2012). Policy news no. 7, III/2012 (in Vietnamese). Center of Human and Nature, Hanoi, Vietnam.

Rahman, M., \& Barua, S. (2016). The design and adoption of green banking framework for environment protection: Lessons from Bangladesh. Australian Journal of Sustainable Business and Society, 2(1), 1-19.

Rahman, M., Hossain, M., Ahsan, M. A., \& Hoq, M. R. (2013). Green banking prospects in Bangladesh. Asian Business Review, 2(2). doi: http://dx.doi.org/10.18034/abr.v2i2.305

Rajput, N., Kaura, R., \& Khanna, A. (2013). Indian banking sector towards a sustainable growth: A paradigm shift. International Journal of Academic Research in Business and Social Sciences, 3(1).

Rambalak, Y., \& Govind, S. P. (2013). Environmental sustainability through green banking: A study on private and public sector banks in India. OIDA International Journal of Sustainable Development, 6(8), 37-48.

Ritter, N. (2010). Understanding a widely misunderstood statistic: Cronbach's alpha. Paper presented at Southwestern Educational Research Association (SERA) Conference 2010, New Orleans, LA (ED526237).

Schultz, C. (2010). What is the meaning of green banking? Retrieved May 2016 from http://greenbankreport.com/green-bank-deals/what-is-the-meaning-of-green-banking/

Singh, H., \& Singh, B. P. (2012). An effective and resourceful contribution of green banking towards sustainability. International Journal of Advances in Engineering Science and Technology, 1(2), $41-45$.

Singh, Y. (2015). Environmental management through green banking: A study of commercial banks in India. International Journal of Interdisciplinary and Multidisciplinary Studies, 2(4), 17-26.

Tran, T. T. T., \& Tran, T. H. Y. (2015). Green bank: International experiences and Vietnam perspectives. Asian Social Science, 11(28), 188-199.

Ullah, M. M. (2010). Green banking in Bangladesh: A comparative analysis. Retrieved February 20, 2013 from http://www.wbiconpro.com/610-Maruf.pdf

United Nations Environmental Programme Finance Initiative (UNEP FI). (2011). UNEP FI guide to banking and sustainability. UNEP Finance Initiative Switzerland. Retrieved from www.unepfi.org/fileadmin/documents/guide_banking_statements.pdf

United Nations Environmental Programme Finance Initiative (UNEP FI). (2014). Stability and sustainability in banking reform: Are environmental risks missing in Basel III? University of Cambridge Institute for Sustainability Leadership. Retrieved from www.unepfi.org/fileadmin/documents/StabilitySustainability.pdf 
Vivid Economics and McKinsey. (2011). The economics of the green investment bank: Costs and benefits, rationale and value for money. Retrieved March 17, 2014 from https://www.gov.uk/government/uploads/system/uploads/attachment_data/file/31741/12-554-economics-of-the-green-investment-bank.pdf

Zhang, B., Yang, Y., \& Bi, J. (2011). Tracking the implementation of green credit policy in China: Top-down perspective and bottom-up reform. Journal of Environmental Management, 92(4), 1321-1327. doi: 10.1016/j.jenvman.2010.12.019 